Petro Pererva,

Doctor of Economics, Professor, Dean of the Economic faculty, National Technical University "Kharkiv Polytechnic Institute" (Kharkiv, Ukraine); Dr. hab, Professor, Higher School of Labour Safety Management - WSZOP (Katowice, Poland);

Tatiana Kobielieva,

Candidate of Economic Sciences, Associate Professor of the Department of Business Administration and Personnel Management, National Technical University "Kharkiv Polytechnic Institute" (Kharkiv, Ukraine);

Maksim Tkachev,

Candidate of Economic Sciences, Associate Professor of the Department of Law, National Technical University "Kharkiv Polytechnic Institute" (Kharkiv, Ukraine);

Nadezhda Tkacheva,

Candidate of Economic Sciences, Associate Professor of the Department of Economics and Marketing National Technical University "Kharkiv Polytechnic Institute" (Kharkiv, Ukraine)

\title{
DETERMINATION OF MARKETING CHARACTERISTICS OF MARKET CAPACITY FOR ELECTRICAL AUTOMATION
}

The problems of determining the marketing characteristics of the market products capacity do not have independent technological purposes. As the object of study selected electrical automation. It is proved that the most important characteristic of the market capacity of goods are the demand for them, which consists of several components. To determine the requirements for electrical automation and maintenance of technological equipment under operation, you need to know the industry Park. The technique of determining industry Park, products which do not have independent technological purpose and which are not maintained inventory records, for example, electrical automation of the basic steps of this methodology. The proposals of the authors based on the determination coefficients the applicability of certain types of electrical automation equipment per unit of basic technological equipment of machine-building industries.

Keywords: park products, electrical automation products, marketing, the coefficients of applicability, processing equipment.

DOI: $10.21272 / \mathrm{mmi} .2017 .3-08$

Problem statement. One of the most important ways of improving commercial activities of industrial enterprises in the target market is the decision of tasks of scientific and economic substantiation of volumes of consumption of different types of products and requirements in [1, 2]. Marketing activities of industrial enterprises in the target market assumes as a critical component of calculations of market capacity. The concept of market capacity is closely related to the concepts of demand and need, in fact, being their quantitative characteristics [3,4]. The market segments have different capacity, as they reflect different uses of the product. For example, electrical automation (EA) are consumed for the needs of the complete set of products of objects of capital construction, repair and maintenance needs of the equipment park, are consumed by the population.

The main object of study is the products of the electrical industry - the major branch of engineering. This industry is among the leading sectors that determine technological progress in the Ukrainian economy. The electrical industry is unique in terms of the breadth and diversity of intersectoral linkages. The industry produced over 90 thousand kinds of products, combined into 20 sub-sectors [2-4]. The main thing that unites the diverse electrical products is its close connection with the electrification of the country. The development of certain types of electrical products crucially depends on the functions that the product performs in its end use, and the changes that occur in the production, transmission, distribution and consumption of electricity. 
The method of calculation of certain types of needs (e.g. the needs of the repair and maintenance of equipment) requires, as a mandatory stage of the calculation, the definition of a Park installed at the consumers. In addition, the equipment (regional, sectoral, national) need to know when determining the number of staff, the calculation of the cost of its maintenance and operation, differentiation of types and models of equipment planning of its production volumes, etc. In this regard, the development of scientificallymethodical bases of definition of the Park's electrical automation (EA) is an important and urgent task.

Analysis of recent researches and publications. Problems of definition of old machinery was considered by such scientists as Aksenkov A.P. [5], Gladenko I.V. [6], Illiashenko S.M. [7-9], Kosenko O.P. [10, 11], Mozenkov O.V. [12], Poberezhna N.M. [13], Starostina A.A. [14], Shipulina Yu.S. [15], Tovazhnyanskiy V.L. [16], Yakovlev A I. [17, 18] etc.

However, in the works of these authors focuses on the assessment of the size of the Park the main technological equipment of machine-building enterprises. For example, in $[3,5,19]$ considers the problem of determining the Park of the process equipment in the chemical and light industries, the authors of works $[6,12,20]$ were limited to the consideration of the Park only economically important equipment. Existing designs also use a variety of approaches to solving the problem of determining the park of products in service. Many authors propose to use the method of direct counting equipment [2, 3 , $5,14,20]$. This is not too difficult, as industrial plants is an inventory record of technology equipment the main item. However, in our opinion, the direct counting method can be acceptable only for the basic types of technological equipment, which are inventory records. Is not, in our view, progressive and methodical approach to setting equipment in value terms $[4,12,15,19]$, because it lost the prospects of using the results of the calculation in the marketing activity of an industrial enterprise.

However, as the results of our research [20-22], the problems of assessing the Park's main technological equipment have been largely solved, and at present this is not so important. Much more urgent and more complicated is the problem of determining the equipment park, which has no independent technological purpose (bearings, motors, pumps, electrical products, computers, light fixtures, measuring instruments, etc.) which the enterprises are not maintained inventory records.

Selection of the unsolved questions. Calculations of actual equipment in operation, for certain types of industrial products have different methodological and regulatory framework. Our research suggests that for electrical automation equipment (contactors, motors, relays, fuses, switches, electromagnets, magnetic starters, transformers, etc.) such a database index is missing. Businesses and industries quantization Park EA is not conducted as to determine it by direct counting almost impossible.

The main purpose of the article is development of methodical provisions of the definition of industry Park electrical automation, has no independent technological purposes. Object of research are machinebuilding enterprises of the Kharkov industrial region.

Research findings. To determine industry Park electrical automation is proposed by studying their applicability (actual presence) in any kind of technological equipment industry Park which is known in advance or can be set in scientific and proven methods. In particular, while defining industry Park low-voltage equipment as a basis we can take the main types of the main technological equipment, asynchronous motors with power up to $100 \mathrm{~kW}$, the amount of generated or consumed in the industry and electricity.

The determination of the direction of research depends on the sector under consideration and its characteristics. A selection of basic representative, which is determined by the ratio of applicability of the EA in this field, cannot be uniquely determined. It is therefore proposed to determine the coefficients of applicability are not for one product but for several, vividly characterize the manufacturing equipment industry. For example, the engineering industry, where the largest number of machine tools (metalcutting, press-forging and foundry). Poets the basis of applicability for electrical automation in the engineering industries are invited to take certain types of machine tools. This approach to defining industry Park EA, in our opinion, will greatly enhance the reliability and validity of the calculations. 
Our recommendations in this area for other industries are given in table 1.

Table 1 - Recommended objects of research to determine industry Park EA (authors' development)

\begin{tabular}{|l|l|l|}
\hline Industry & Recommended objects of research & Note \\
\hline Ferrous metallurgy & Converters, blast furnaces, open-hearth furnaces, blooming, slabs & The main method \\
\hline Chemical & Motors & \\
\hline Forestry and woodworking & Woodworking machines, parts, production lines & The main method \\
\hline Oil and gas & Drilling rigs & \\
\hline Electricity & Magnetic control station & \\
\hline Agriculture & Asynchronous motors & \\
\hline Coal mining & Magnetic control station & \\
\hline Transport & The types of vehicles & \\
\hline Light and food & The electricity consumption & \\
\hline
\end{tabular}

In the most General form of the calculation formula industry Park i-th type of EA is as follows:

$$
N_{i}=N_{j} \cdot K_{i j},
$$

where $N_{j}$ - Industrial Park $j$-th type of equipment for which the coefficient of applicability of the $i$-th type EA $K_{j j}$.

In relation to engineering industries for certain types of the main technological equipment of formula (1) takes a more complex form:

$$
N_{i}=\sum_{j=1}^{J=n}\left(N_{j} \cdot K_{i j}\right)
$$

where $j$ - is the type of process equipment - metal-cutting, press-forging, foundry; $n$ - number of types of the main technological equipment (in this case, $n=3$ ).

The practical calculation of coefficients $K_{i j}$ of applicability should be given special attention, as these values represent the most important components when you use these guidelines. The method of their calculation and justification boils down to consistent work in the following interrelated stages.

1. First made a classification of the selected object of study for a number of distinctive groups or types of products. For example, for engineering industries (machine tools, electrical engineering, instrumentation, automotive, etc.) selected objects studies - metal-cutting machines, press-forging and foundry equipment is broken even for a number close by their design and technological content of group assignments. The results of this classification are given in table 2.

It should be noted that given in table 2 classification of the main technological equipment may not be applicable for all branches of engineering. In such cases, more research is needed in order to carry out such a classification.

2. For each of the classification groups and sub-groups of technological equipment, an analysis of old machinery to identify and model the most massive application. The total Park selected models in total should be quite a representative sample - not less than $70-80 \%$ of the total industry Park of technological equipment.

3. Examines electrical circuits, or picking list of selected process equipment models with the purpose of revealing in them of the number of individual types of EA. This is the most time-consuming step of the calculation, despite its simplicity. Of how well and faithfully he performed, depends on the accuracy of the final results, the result by definition of industry Park EA. 
П.Г. Перерва, Т.О. Кобєлєва, М.М. Ткачов, Н.П. Ткачова. Визначення маркетингових характеристик місткості ринку електротехнічних засобів автоматизації

Table 2 - Classification of subgroups of the main technological equipment of machine-building industries (compiled by the authors based on data of enterprises)

\begin{tabular}{|c|c|c|c|}
\hline $\begin{array}{c}\text { Group } \\
\text { number }\end{array}$ & Metal cutting machines & Press-forging equipment & Foundry equipment \\
\hline 1 & Lathes and turret & Presses, hydraulic, pneumatic & Sand plant machine \\
\hline 2 & Drilling & Presses, mechanical & Mounding machine \\
\hline 3 & Boring & Machines & The core-making machine \\
\hline 4 & Grinding & Hammers & Kick machine \\
\hline 5 & Gear & Forging machine & Water treatment machine \\
\hline 6 & Planing, slotting and broaching & Correct and bending machine & Machines for investment casting \\
\hline 7 & Milling & Scissors & Shell-molding \\
\hline 8 & Aggregate & - & Chill casting \\
\hline 9 & - & - & Centrifugal casting \\
\hline 10 & - & - & Injection molding \\
\hline
\end{tabular}

4. Calculation of the coefficients of applicability of a particular type of EA for this group classification of the main technological equipment (pieces per unit). The estimated relationship has the following form:

$$
K_{i j}^{s}=\frac{\sum_{n=1}^{m} K_{i j}^{s n} \cdot O_{s n}}{\sum_{n=1}^{m} O_{s n}},
$$

where $K S_{i j}$ - coefficient of applicability in the $i$-th form of EA for the $s$-th classification group $j$-th type of process equipment, units per unit of equipment; $O_{s n}$ - industry Park of the $n$-th model $s$-th groups of technological equipment; $K^{s n_{i j}}$ - the number pieces $i$-th species EA at the $n$-th model $s$-th group of equipment of the $j$-th species.

The result of this phase is to determine the coefficients of applicability of certain types of types of EA models for specific technological equipment. The basis for such calculations are the norm configuration electrical diagrams of the individual models in this classification groups of technological equipment, as well as their quantity in the industrial Park.

5. Calculation of the coefficients of applicability in the specific EA unit j-th species Kij:

$$
K_{i j}=\sum_{s=1}^{l} K_{i j}^{s} \cdot \gamma_{j s},
$$

where $I$ - the number of classification groups of technological equipment of this type; $\gamma_{j s}$ - share $s$-th classification group in the industrial Park of the $j$-th type of process equipment. This should respect the condition:

$$
\sum \gamma_{j s}=1
$$

According to this method were determined the coefficients of the applicability of various EA on metalcutting, press-forging and foundry equipment, the practical application of which allows to identify Park EA for engineering industries.

The study was conducted at 18 machine-building enterprises of the Kharkov industrial region. An analysis was made of the actual availability of various types of electrotechnical automation in electric control circuits for metal cutting, forging and molding equipment and foundry equipment, taking into 
account their service life and the years of manufacture (release).

Using the apparatus of mathematical statistics $[1,12,20]$, the validity of applicability coefficients and the possibility of their use in determining the ESA industrial park were verified. The calculations made allow us to conclude that the calculated coefficients of applicability of ESA on various types of technological equipment with the probability of $95 \%$ can be used as industry ones, having abandoned the labor-intensive method of direct counting.

As an example, in table 3 shows calculation results of the coefficients of applicability of electromagnetic actuators for different nominal currents for cutting equipment. Rooms separate groups of cutting equipment conform to the classification given in table 2 .

Table 3 - Coefficients of the applicability of electromagnetic actuators for metal cutting equipment (authors' development)

\begin{tabular}{|l|c|c|c|c|c|c|c|c|c|}
\hline $\begin{array}{c}\text { Electromagnetic } \\
\text { contactors for } \\
\text { nominal currents, A }\end{array}$ & 1 & 2 & 3 & 4 & 5 & 6 & 7 & 8 & $\begin{array}{c}\text { The recommended } \\
\text { use of one cutting } \\
\text { machine }\end{array}$ \\
\hline 10 & 1,57 & 1,62 & 2,80 & 4,02 & 1,36 & 0,94 & 1,84 & 3,35 & 1,56 \\
\hline 25 & 1,21 & 0,61 & 0,22 & 0,85 & 1,57 & 1,25 & 1,56 & 6,05 & 1,34 \\
\hline 40 & 0,45 & 0,05 & 0,07 & 0,27 & 1,28 & 0,11 & 1,11 & 0,06 & 0,31 \\
\hline 63 & 0,07 & 0,012 & - & 0,142 & 0,09 & 0,046 & 0,33 & - & 0,08 \\
\hline 100 & 0,014 & - & - & 0,04 & 0,024 & 0,260 & - & 0,13 & 0,02 \\
\hline
\end{tabular}

The analysis of the coefficients of applicability of EA in various groups of cutting equipment allows making a conclusion about the different level of automation. It is the biggest level of automation characteristic of aggregate (about 10 electromagnetic actuators for 1 machine) and grinding (over electromagnetic actuators for 1 machine) machines. It should be noted that every two electromagnetic actuator provides a single asynchronous motor, which directly provide automation of process equipment, converting electrical energy into mechanical energy.

In table 4 provides a generalized aggregated data on the coefficients of applicability to various types of technological equipment in the engineering industries.

\section{Table 4 - Coefficients of the applicability of various EA at the basic types of technological equipment in the sectors of mechanical engineering (authors' development)}

\begin{tabular}{|l|l|l|l|}
\hline \multirow{2}{*}{ The types of EA } & \multicolumn{3}{l|}{ The coefficients of applicability of unit process equipment, pieces } \\
\cline { 2 - 4 } & Cutting & Forging & Foundry \\
\hline Circuit breakers & 1,819 & 1,590 & 2,181 \\
\hline Electromagnetic contactors & 3,010 & 3,898 & 5,371 \\
\hline Control buttons & 4.353 & 5,433 & 5,278 \\
\hline Relay & 2,751 & 5,535 & 2,858 \\
\hline The end switches and travel & 2,376 & 1,620 & 3,852 \\
\hline Electromagnetic clutches and magnets & 0,875 & 2,092 & 3,044 \\
\hline Fuses & 0,931 & 0,530 & 1,974 \\
\hline Switches & 2,304 & 0,850 & 2,460 \\
\hline Transformers & 1,124 & 1,323 & 1,092 \\
\hline Light fixture & 1,320 & 1,457 & 1,365 \\
\hline Terminals & 12,343 & 26,649 & 16,672 \\
\hline The switches & 0,342 & 0,211 & 0,196 \\
\hline Thyristor contactless starters & 0,769 & 0,387 & 0,118 \\
\hline Other types of EA & 0,649 & 0,841 & 0,548 \\
\hline
\end{tabular}

It is s similar scheme for determining the coefficients of applicability applicable to electric motors with a capacity of $0.25-100 \mathrm{~kW}$, the basic classification which is the height of rotation from 63 to $250 \mathrm{~mm}$ (total 12 major groups of electric motors). The result of the research, determined the coefficients of the 
П.Г. Перерва, Т.О. Кобєлєва, М.М. Ткачов, Н.П. Ткачова. Визначення маркетингових характеристик місткості ринку електротехнічних засобів автоматизації

applicability of electric motors: one cutting machine $-2,19$ pieces of motors; one forging machine 1,25 pieces of motors; one casting machine $-1,87$ pieces of electric motors.

When calculating industry Park Electricals for aggregated item (without specifying a specific series and types of EA) you can use the coefficients of the applicability of EA on individual types of equipment, designed a simplified method when using only two quantities:

a) scope of supply ENA to the complete set of products of the engineering industry that manufactures the j-th type of process equipment;

b) production volume of $j$-th type of equipment. Disclaimer «enlarged to the item» due to the fact that the statistical record of supply EA plans the logistics of machine-building enterprises is carried out in terms of value for this type of EA and in natural - on the most important groups of this type of EA.

For example, for low-voltage equipment such groups are magnetic starters, circuit breakers, relays, solenoids, and final limit switches, etc.

Conclusions. The production and consumption of electrical automation is not only about mechanical engineering. In almost any industry they are pivotal in the implementation of electrification, modernization, mechanization, automation and intensification of production processes. With such a wide variety of applications of electrical products requires the development of comprehensive measures for the development of planning and forecasting of production and sales from the standpoint of effective demand, which implies the improvement of methods of determining current and future needs in ENA for various needs. The authors proved that the indicator of industry Park EA is the most important factor of formation of demand and need for these products for the following types of needs: repair of EA that are currently in operation; replacement of products that fail; replenishment and expansion of the existing Park; replacement of obsolete models of EA; for stockpiles of electrical equipment to ensure smooth operation of the main technological equipment.

The proposals of the authors based on the determination coefficients the applicability of certain types of electrical automation equipment per unit of basic technological equipment of machine-building industries. All theoretical concepts are accompanied by detailed examples of calculations.

Prospects of further studies associated with the development of methods for statistical evaluation of the obtained coefficients, the applicability of EA on the main technological equipment of machinebuilding industries. In addition, an extremely interesting area is the modeling of size industry Park EA for medium and long term. The results of these studies can form the normative basis of the planned production of the enterprises of electrotechnical profile.

Continuation will be published in № 42017.

1. Економіка підприємства: магістерський курс / за ред. проф. Загірняка М.В. - Кременчук: ТОВ «Кременчуцька міська друкарня», 2015 - 756 c.

2. Кухній Л.С. Розвиток підприємств електротехнічної галузі як передумова успішного функціонування на ринку / Л.С. Кухній // Галицький економічний вісник. - 2016 - Том 50. - №1. - С. 47-54.

3. Кобєлєва Т.О. Електротехнічна галузь України: сучасний стан та перспективи розвитку // Т.О. Кобєлєва // Вісник НТУ «ХПІ». - Харків, 2011.- № 26. - С. 34-43.

4. Перерва, П.Г. Потребность в электротехнических средствах автоматизации. Теория и методы определения [монография] / П.Г. Перерва. - Харків : Основа, 1991. - 114 с.

5. Аксенов А.П. Экономика и организация ремонта парка оборудования / А.П. Аксенов. - Москва : Изд-во МГТУ им. Н.Э.Баумана, 2005. -38 с.

6. Гладенко І.В. Науково-методичні підходи до вирішення проблем практичної реалізації механізму комерціалізації об'єктів інтелектуальної власності / І.В.Гладенко, А.В.Косенко // Вісник Національного технічного університету «Харківський політехнічний інститут». Технічний прогрес і ефективність виробництва. - Харків : НТУ"ХПІ". - 2008. - №18. - С. 105-110.

7. Маркетинг. Менеджмент. Інновації: монографія / С.М.Ілляшенко [та ін.]; заг. ред. С.М.ІІлляшенко. - Суми : ТОВ «ДД «Папірус», 2010. - 621 с.

8. Маркетинг інновацій і інновації в маркетингу : монографія / С.М.ІІлляшенко [та ін.]; заг. ред. С.М.ІІлляшенко. - Суми : Університетська книга, 2008. -615 с.

9. Проблеми і перспективи ринково-орієнтованого управління інноваційним розвитком: монографія / за ред. д.е.н., проф. С.М. Ілляшенка. - Суми: ТОВ «ДД «Папірус», 2011. - 644 с.

10. Косенко, А.П. Экономическая оценка инновационного потенциала / А.П.Косенко.- Харьков-Мишкольц : НТУ „ХПИ”, Мишкольц.техн.ун-т, 2009. - 170 с. 
11. Косенко, О. П. Комерціалізація інтелектуально-інноваційних технологій : монографія / О.П. Косенко. - Харків : НТУ "ХПІ", 2015. - 599 c.

12. Яковлєв А.І. Методи оцінки збитку на підприємствах при виході з ладу електротехнічного обладнання : монографія / А. І. Яковлєв, О. В. Мозенков, В.М. Кобєлєв. - Харків : ВВП "Контраст", 2012. - 120 с.

13. Побережна Н.М. Визначення ефективності використання виробничого потенціалу машинобудівного підприємства [Текст] / Н.М. Побережна // Маркетинг і менеджмент інновацій. - 2012. - №2. - С. 191-198.

14. Старостіна А.О. Маркетинг / за заг. ред. Старостіної А.О. - К.: Знання, 2009. - 1070 с.

15. Механізм управління потенціалом інноваційного розвитку промислових підприємств: монографія / за ред. к.е.н. доцента Ю.С. Шипуліної. - Суми: ТОВ «ДД «Папірус», 2012. - 458 с.

16. Товажнянський В.Л. Антикризовий моніторинг фінансово-економічних показників роботи машинобудівного підприємства / В.Л.Товажнянський // Економіка розвитку. - 2010 - № 2. - С. 46-50.

17. Яковлєв А.І. Аналіз сучасного стану інтелектуально-інноваційної діяльності в Україні / А.І. Яковлєв, О.П. Косенко, М.М. Ткачов // Вісник Національного технічного університету «ХПІ». Серія : Технічний прогрес та ефективність виробництва. - 2015. - № 25. - С. 162-174.

18. Яковлєв А.І. Комерціалізація інтелектуальної власності: проблеми визначення та правового забезпечення / А.І. Яковлєв, О.П. Косенко, М.М. Ткачов // Маркетинг інновацій i інновації у маркетингу : збірник тез доповідей VII Міжнародної науково-практичної конференції, 26-28 вересня 2013 р. - Суми : ТОВ "ДД "Папірус", 2013. - С. 309-311.

19. Государство и рынок: механизмы и методы регулирования в условиях перехода к инновационному развитию / Под ред. С.А. Дятлова, Д.Ю. Миропольского, В.А. Плотникова. Санкт-Петербург : Изд-во Астерион, 2010. - 374 с.

20. Экономика и управление инновационной деятельностью / Под ред. проф. Вороновского Г.К., проф. Меховича С.А., проф. Погорелова Н.И. - Харьков: НТУ «ХПИ», 2009. - 1203 с.

1. Zagirnyak, M.V. (Eds.) (2015). Yekonomika pidpriemstva: magisterskiy kurs [Economics of the enterprise: master's course]. Kremenchuk: TOV «Kremenchutska miska drukarnya», 2015 [in Ukrainian].

2. Pererva, P.G. (1991). Potrebnost $v$ elektrotehnicheskih sredstvah avtomatizatsii. Teoriya i metodyi opredeleniya [The need for electrical automation. Theory and methods of determination]. - Kharkiv : Osnova [in Russian].

3. Kukhniy, L.S. (2016). Rozvitok pidpriemstv yelektrotekhnichnoi galuzi yak peredumova uspishnogo funktsionuvannya na rinku [Development of enterprises of the electrical engineering industry as a precondition for successful functioning in the market] Galitskiy yekonomichniy visnik - Galician Economic Herald, 1 (50), 47-54. [in Ukrainian].

4. Kobyelyeva, T.O. (2011). Elektrotekhnichna haluz Ukrayiny: suchasnyy stan ta perspektyvy rozvytku [Electrical industry of Ukraine: current state and development prospects]. Tekhnichniy progres i yefektivnist virobnitstva - Technical progress and production efficiency, 26, 34-43 [in Ukrainian].

5. Aksenov, A.P. (2005) Ekonomika i organizatsiya remonta parka oborudovaniya [Economy and organization of repair of equipment parks]. Moscow: MGTU them. N. E. Baumana [in Russian].

6. Gladenko, I.V., \& Kosenko, A.V. (2008). Naukovo-metodichni pidkhodi do virishennya problem praktichnoi realizatsii mekhanizmu komertsializatsii obektiv intelektualnoii vlasnosti [Scientific and methodical approaches to solving problems of practical implementation of the mechanism of commercialization of intellectual property objects]. Tekhnichniy progres $i$ yefektivnist virobnitstva - Technical progress and production efficiency, 18,105-110 [in Ukrainian]

7. Illiashenko, S.M. (Eds.) (2010). Marketyng. Menedzhment. Innovaciyi [Marketing. Management. Innovations]. Sumy : TOV «Drukarskyj dim «Papirus» [in Ukrainian].

8. Illiashenko, S.M. (Eds.). (2008) Marketyng innovatsiy i innovatsii v marketingu [Marketing of innovation and marketing in marketing].- Sumi : Universitetska kniga [in Ukrainian].

9. Illiashenko, S.M. (Eds.) (2011). Problemy i perspektyvy rynkovo-oriyentovanogo upravlinnya innovacijnym rozvytkom: monografiya [Problems and prospects of market-oriented innovative development management]. Sumy: TOV «Drukarskyj dim «Papirus» [in Ukrainian].

10. Kosenko, A.P. (2009). Ekonomicheskaya otsenka innovatsionnogo potentsiala [Economic Assessment of Innovation Capacity]. Kharkov-Mishkolts : NTU „KHPI” [in Russian].

11. Kosenko, O.P. (2015). Komertsializatsiya intelektualno-innovatsiynikh tekhnologiy : monografiya [Commercialization of intellectual and innovative technologies]. Kharkiv : NTU «KHPl» [in Ukrainian].

12. Yakovlev, A.I., Mozenkov, O.V., \& Kobelev, V.M. (2012). Metodi otsinki zbitku na pidpriemstvakh pri vikhodi z ladu yelektrotekhnichnogo obladnannya [Methods of estimation of damage at enterprises at failure of electrical equipment]. Kharkiv : VVP «Kontrast» [in Ukrainian].

13. Poberezhna, N.M. (2012). Viznachennya yefektivnosti vikoristannya virobnichogo potentsialu mashinobudivnogo pidpriemstva [Determination of efficiency of use of production potential of machine-building enterprise]. Marketynh i menedzhment innovatsii - Marketing and Management of Innovations, 2, 191-198 [in Ukrainian].

14. Starostina, A.O. (Eds.) (2009). Marketyng [Marketing]. Kyiv : Znannia [in Ukrainian].

15. Shypulina, Yu.S. (Eds.) (2008). Mexanizm upravlinnya potencialom innovacijnogo rozvytku promyslovyx pidpryyemstv: monografiya [The management mechanism of innovative potential development of industrial enterprises]. Sumy: TOV «DD «Papirus» [in Ukrainian]

16. Tovazhnyanskiy, V.L. (2010). Antikrizoviy monitoring finansovo-yekonomichnikh pokaznikiv roboti mashinobudivnogo pidpriemstva [Anti-crisis monitoring of financial and economic performance of the machine-building enterprise]. Yekonomika rozvitku - Development Economics, 2, $46-50$ [in Ukrainian]. 
17. Yakovlev, A.I., Kosenko, O.P., \& Tkachov, M.M. (2015). Analiz suchasnogo stanu intelektualno-innovatsiynoi diyalnosti v Ukraini [Analysis of the current state of intellectual and innovation activity in Ukraine]. Tekhnichniy progres $i$ yefektivnist virobnitstva - Technical progress and production efficiency, 25, 162-174. [in Ukrainian].

18. Yakovlev, A.l., Kosenko, O.P., \& Tkachov, M.M. (2013). Komertsializatsiya intelektualnoi vlasnosti: problem viznachennya ta pravovogo zabezpechennya [Intellectual Property Commercialization: Problems of Definition and Legal Enforcement]. Proceedings from MIIM '13: VII Mizhnarodna naukovo-praktychna konferentsiia «Marketynh innovatsii i innovatsii v marketynhu» - The Seventh International Scientific and Practical Conference "Marketing of Innovations and Innovations in Marketing». (pp. 309-311). Sumy: TOV «DD «Papirus» [in Ukrainian].

19. Dyatlov, S.A., Miropolskii, D.Yu., \& Plotnikov, V.A. (2010). Gosudarstvo i rynok: mekhanizmy i metody regulirovaniya v usloviyakh perekhoda $k$ innovatsionnomu razvitiyu [State and market: mechanisms and methods of regulation in conditions of overcoming crisis and transition to innovative development]. Saint Petersburg: Asterion [in Russian].

20. Voronovskii, G.K., Mekhovich, S.A., \& Pogorelov, N.I. (2009). Ekonomika i upravleniye innovatsionnoy deyatelnostyu: uchebnik [Economics and management of innovation]. Kharkov: NTU «KhPI» [in Ukrainian].

П.Г. Перерва, д-р екон. наук, професор, декан економічного факультету НТУ «Харківський політехнічний інститут» (м. Харків, Україна); д-р хабілітований, професор, Вища школа управління та охорони праці (м. Катовіце, Польща):

T.O. Кобєлєва, канд. екон. наук, доцент кафедри організації виробництва, НТУ «Харківський політехнічний інститут» (м. Харків, Україна);

M.M. Ткачов, канд. екон. наук, доцент кафедри права, НТУ «Харківський політехнічний інститут» (м.Харків, Україна);

Н.П. Ткачова, канд. екон. наук, доцент кафедри економіки і маркетингу, НТУ «Харківський політехнічний інститут» (м. Харків, Україна)

Визначення маркетингових характеристик місткості ринку електротехнічних засобів автоматизації

Розглянуто питання визначення маркетингових характеристик місткості ринку виробів, що не мають самостійного технологічного призначення. В якості об'єкта дослідження вибрано електротехнічні засоби автоматизації. Доведено, що найважливішою характеристикою ємності ринку виробів є потреба у них, яка складається з декількох складових. Для визначення потреби в електротехнічних засобах автоматизації на ремонт і експлуатацію технологічного обладнання, що знаходяться в експлуатації, необхідно знати його галузевої парк. Розроблена методика визначення галузевого парку виробів, що не мають самостійного технологічного призначення і за якими не ведеться інвентаризаційний облік. На прикладі електротехнічних засобів автоматизації розглянуто основні етапи даної методики. Пропозиції авторів побудовані на визначенні коефіцієнтів застосування окремих типів електротехнічних засобів автоматизації на одиницю основного технологічного обладнання в машинобудівних галузях.

Ключові слова: парк виробів, електротехнічні засоби автоматизації, маркетинг, коефіцієнти вживаності, технологічне обладнання.

П.Г. Перерва, д-р экон. наук, профессор, декан економического факультета НТУ «Харьковский политехнический институт (г. Харьков, Украина); д-р хабилитированный, профессор, Высшая школа управления и охраны труда (г. Катовице, Польша);

T.A. Кобелева, канд. экон. наук, доцент кафедры организации производства и управления персоналом НТУ «Харьковский политехнический институт (г. Харьков, Украина);

М.М. Ткачев, канд. экон. наук, доцент кафедры права НТУ «Харьковский политехнический институт (г. Харьков, Украина);

Н.П. Ткачева, канд. экон. наук, доцент кафедры экономики и маркетинга НТУ «Харьковский политехнический институт» (г. Харьков, Украина)

Определение маркетинговых характеристик емкости рынка электротехнических средств автоматизации

Рассмотрены вопросы определения маркетинговых характеристик емкости рынка изделий, не имеющих самостоятельного технологического назначения. В качестве объекта исследования выбраны электротехнические средства автоматизации. Доказано, что важнейшей характеристикой емкости рынка изделий являются потребность в них, которая состоит из нескольких составляющих. Для определения потребности в электротехнических средствах автоматизации на ремонт и эксплуатацию технологического оборудования, находящихся в эксплуатации, необходимо знать его отраслевой парк. Разработана методика определения отраслевого парка изделий, не имеющих самостоятельного технологического назначения и по которым не ведется инвентаризационный учет. На примере электротехнических средств автоматизации рассмотрены основные этапь данной методики. Предложения авторов построены на определении коэффрициентов применяемости отдельных типов электротехнических средств автоматизации на единицу основного технологического оборудования в машиностроительных отраслях.

Ключевые слова: парк изделий, электротехнические средства автоматизации, маркетинг, коэффициенты применяемости, технологическое оборудование.

Отримано 15.03.2017 p. 